This item was submitted to Loughborough's Research Repository by the author.

Items in Figshare are protected by copyright, with all rights reserved, unless otherwise indicated.

\title{
Between 'soft power' and a hard place: European Union Foreign and Security Policy between the Islamic world and the United States
}

PLEASE CITE THE PUBLISHED VERSION

http://dx.doi.org/10.1057/ip.2009.15

PUBLISHER

(C) Palgrave Macmillan

VERSION

AM (Accepted Manuscript)

LICENCE

CC BY-NC-ND 4.0

\section{REPOSITORY RECORD}

Smith, Michael H.. 2019. "Between 'soft Power' and a Hard Place: European Union Foreign and Security Policy Between the Islamic World and the United States”. figshare. https://hdl.handle.net/2134/15009. 
This item was submitted to Loughborough's Institutional Repository (https://dspace.lboro.ac.uk/) by the author and is made available under the following Creative Commons Licence conditions.

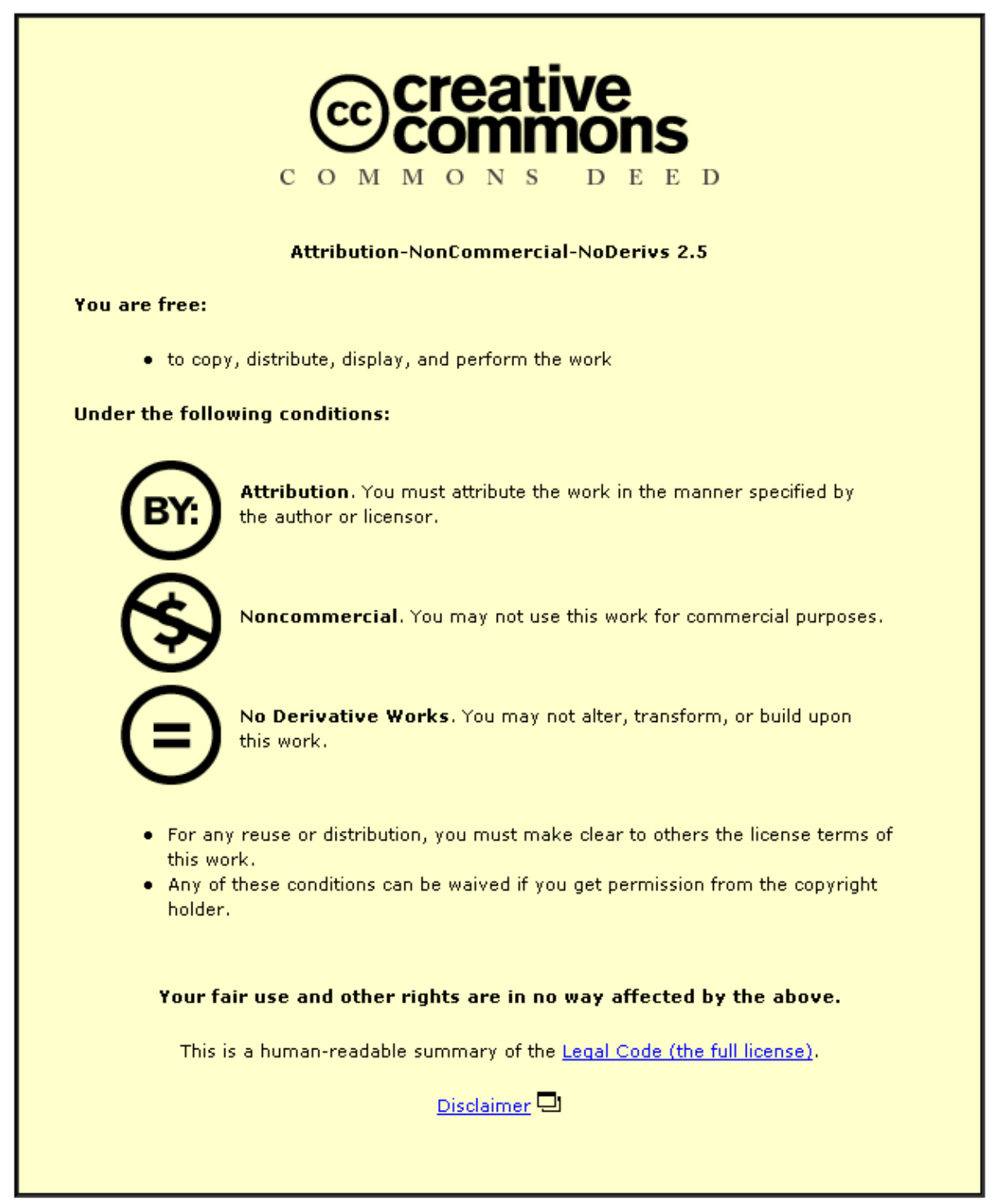

For the full text of this licence, please go to: http://creativecommons.org/licenses/by-nc-nd/2.5/ 


\title{
Between 'Soft Power' and a Hard Place: European Union Foreign and Security Policy Between the Islamic World and the United States
}

\author{
Michael Smith \\ Loughborough University, UK
}

\begin{abstract}
This article explores the pressures operating on European Union Foreign and Security Policy in the 'triangle of forces' created by the European integration process, developments in the Islamic world and the responses of the United States. In the first section, the article explores ideas about foreign policy and power in the EU, as exemplified in debates about the Lisbon Treaty and the future role of the Union. The second part of the paper sets out three logics inherent in the development of the Common Foreign and Security Policy, distinguishing between the 'internal' logic of the European integration process, the 'external' logic reflecting the opportunity structure in the world arena, which creates challenges and opportunities for the EU and its Member States, and the 'identity' logic, which creates a move towards selfrealisation and 'self-recognition' on the part of the EU in international politics, and relates this to recent developments in European foreign and security policy. The article then argues that the multi-dimensional 'triangle of forces' between European integration, the Islamic world and the United States has played a key role in focusing these developments, by posing challenges to the three logics and creating complex linkages between them. The Conclusion asks whether as a result EU foreign policy has been 'catalysed' (given new impetus and direction) or 'constrained' (subject to a process of external or self-limitation).
\end{abstract}

Keywords: European Union; foreign and security policy; United States; Islam

\section{Introduction}

The development of European foreign policy, understood here as the collective external action of European Community (EC) and then European Union (EU) Member States has been a key feature of the European integration project since the late 1960s (Allen and Wallace 1977; Forster 2004; Forster and Wallace 1996, 2000; Nuttall 1992, 2000; Peterson and Sjursen 1998; Wallace 2005). The first stage of this development entailed the elaboration of the essentially intergovernmental structures of European Political Cooperation, which were formalised in the London Report of 1981 and then in the Single European Act of 1985. The Maastricht Treaty of 1991 then proclaimed the establishment of a Common Foreign and Security Policy (CFSP), which was further consolidated in the Amsterdam Treaty of 1997 and the Nice Treaty of 2000. During the late 1990s, moves were initiated to go beyond the CFSP and create what has since become the European Security and Defence Policy (ESDP) (Howorth 2005, 2007). As a result, not only has 
the European Union developed a system of continuous diplomatic coordination through the CFSP, it has also begun to create the capacity to deploy military power, albeit in a restricted range of contexts and with a restricted set of purposes. Arguably, this process has made the EU into a diplomatic and even military 'power' to range alongside the leading states within the world arena (Hill and Smith 2005: Introduction and Conclusion); but as the treatment of foreign policy issues in the Constitutional Treaty negotiations and the build-up to the Lisbon Treaty of 2007 showed, there is still a great deal of contestation around this issue arising out of the divergent preferences of leading EU Member States.

One key feature of the long and often contested evolution of European foreign policy is its close relationship to the development of key issues within the world arena. Most obviously, the end of the Cold War created a new impetus towards foreign policy cooperation among EU Member States, both for defensive reasons and for more positive reasons connected with the promotion of a 'European model' in diplomacy and conflict management. In a longer-term perspective, the links between the evolution of European foreign policy and the problematic nature of American leadership within the 'Western Alliance' have been well-documented (Allen and Smith 1989; McGuire and Smith 2008; Peterson 1996; Peterson and Pollack 2003; Smith 2005).

In the context of this article, though, it is of the greatest importance that European foreign policy has frequently been catalysed or constrained by the development of relations between the United States, Europe and the Islamic world. Initially, the key focus of this entanglement was the Arab-Israeli dispute, especially in the context of the October War, the 1970 s oil crises and the increasing attention to the issue of the Palestinians (Allen and Pijpers 1982). The 1980s Venice Declaration of the European Community was a first significant sign that the collective diplomatic position of the Europeans might diverge from that of the Americans and Israel; the rights of the Palestinians and the centrality of the issue of Palestinian statehood have remained key to European collective positions ever since. Since the end of the Cold War, the EU has played an active role in the 'greater Middle East' both diplomatically through the CFSP and more broadly in the provision of support for peacebuilding processes, and have become an established member of the 'quartet' 
attempting to sponsor a long-term peace framework (Ortega 2003; Youngs 2006). But there are paradoxical elements to the EU's involvement: for example, although the Union is heavily involved with support for the Palestinian Authority, and has a significant economic relationship with Israel extending to a customs union, it appears to have very little leverage on events (O'Donnell 2008).

Although the Israel-Palestine issue remains at the core of EU diplomacy, there has grown up during the past decade a much broader and more challenging engagement with the putative 'clash of civilisations' between the West and the Islamic world, which has a particular resonance for the EU given its proximity to several arenas of conflict and the historical entanglement of many EU Member States with Muslim cultures and populations. The conflicts in former Yugoslavia during the 1990s, and especially those over Bosnia-Herzegovina and Kosovo, were and remain challenging for the EU; the crystallising events of September $11^{\text {th }} 2001$ and the subsequent 'war on terror' have multiplied the challenge and given it new dimensions linked with broader global insecurities; and the continuing tensions surrounding enlargement of the EU to encompass Turkey have confronted EU institutions and Member States with further inescapable pressures (Youngs 2006).

How well has European foreign policy served the EU in responding to these challenges? And how might the challenges be dealt with in the future? In order to understand at least some of the answers to these questions, this article examines in detail the forces lying behind recent developments in European foreign policy, and relates those forces to the challenges and opportunities arising from developments in the 'triangle of forces' constituted by Europe, the United States and the Islamic world. First, it presents a short review of the notion of the EU as a 'power', with attention to the relationship between 'soft' and 'hard' power, and relates this to the perspectives of policymakers. Second, it sets out the three key logics that seem to drive the development of European foreign policy, and explores some key trends emerging from those logics. Finally, it relates the earlier argument directly to the ways in which the EU finds itself as part of the 'triangle of forces' composed of itself, the US and the Islamic world, and takes up a number of the central themes in this Special Issue. The article concludes by suggesting 
some potential futures for the relationships, linking them to the potential future of European foreign policy.

\section{Foreign Policy, Power and the European Model}

There is well established interest in the ways in which the European Union (EU) has become a 'power' in international politics, and to exploration of the implications of this status (Hill and Smith 2005: Introduction and Conclusion; Sjursen 2007; Aggestam 2008). A key strand of discussion has been the analysis of the relationship between 'soft' or 'civilian' power (often also linked with arguments about 'normative power' or 'ethical' power') and 'hard power', linked with the development of a 'real' foreign policy for the EU (Manners 2006; K. Smith 2005; M. Smith 2006b). Often, the analysis has been extended into consideration of issues such as roles and identity, on the assumption that these issues can be explored in order to provide a deeper understanding of the dynamics of European foreign policy formation, and of the ways European foreign policy works when projected into the external world (Elgström and Smith 2006; Aggestam 2004). European foreign policy is thus in some ways a test-bed for the exploration of key theoretical issues about foreign policy in a post-sovereign and post-Cold War world (Sjursen 2003; M. Smith 2003; White 2001). In particular, the EU's move along the spectrum between 'soft' power and 'hard' power, and the implications for legitimacy and accountability in European foreign policy, have formed a key conceptual focus.

'European foreign policy', though, is not simply a field for the study of abstractions and for intellectual sport. It is one of the key arenas for political contestation in setting the agenda for the future development of the EU itself. For evidence, one need look no further than recent reflections by policy makers in a range of EU Member States. The debates surrounding both the negotiations on the failed Constitutional Treaty and the subsequent Lisbon Treaty and the development of a longer term perspective on the EU's role in the world have centred on a number of key themes: the need to maintain European prosperity and security, the potential of the EU as a model of regional cooperation, and the need in this cause to deploy both 'soft' and 'hard' power in the promotion of democracy and the treatment of conflict in the wider world (Gnesotto and Grevi 2006). In the words of the British Foreign 
Secretary, David Miliband, this did not mean that the EU could or should become a Superpower, in the sense of a potential global hegemon; rather, it should (must?) become a 'model power' providing a role model and using its 'soft' and 'hard' power to promote a civilised world (Miliband 2007). In doing this, it shared both values and aims with the USA: '...there is a great shared project for Europe and America, to embed our values and commitments in international rules and institutions'.

Such arguments centred not only on a set of established analytical perspectives dealing with European foreign policy, but also on ideas about regional and global governance that have a far broader resonance. There is an intimate connection between conceptions of the EU's international role and the responsibilities that might logically follow from that. Thus Miliband in common with many others pointed to four specific principles that (he argued) would make roles and responsibilities operate fruitfully together: openness to trade, ideas and investment; the use of the power of 'shared institutions and shared activities' to help overcome religious, regional and cultural divides, especially with the Islamic world; the championing of international law and human rights on a global scale, backed up by the development of new 'hard power' capabilities where necessary; and the pursuit of ambitious targets in the area of environmental damage-limitation, based on the internal environmental regimes established within the Union. Surrounding debates about the revision of the 2003 European Security Strategy encouraged further reflection about the range of principles the $\mathrm{EU}$ wishes to pursue and the range of resources that might be available to pursue them in the future, with a particular emphasis on the pursuit of multilateralism and the deployment of 'soft power' (Gnesotto and Grevi 2006; Grevi 2008).

What is striking about the debates on the future of European foreign policy is their focus on the relationship between soft and hard power, and also their focus on relations with both the United States and the Islamic world as one acid test of the EU's international impact and credibility. The debates also centred, directly or indirectly, on a number of key assumptions that will be scrutinised in what follows. First, many policy makers identified what might be termed a 'triangle of forces' constituted by the EU, the US and the Islamic world, in which a number of key tests are posed by the interaction of policies 
and values. Second, they linked this to the development by the EU of a more substantial foreign and security policy that links together not only 'soft' or 'civilian' power but also increasing elements of 'hard' power', thus arguably making it into something approximating a 'real' foreign policy. Third, the debates indirectly responded to three key logics in the development of European foreign policy: what might be termed the 'integration logic', the 'external logic' and the 'identity logic'. Finally, the debates linked the legitimacy and credibility of European foreign policy to key tests arising from the interaction of the West with the Islamic world: Iraq and the Lebanon, Afghanistan, and enlargement to include Turkey, defined as a foreign policy issue for the EU (Barysch, Everts and Grabbe 2005, Youngs 2006). These are the themes that this article will pursue, since they raise vital analytical and practical questions about the ways in which the EU can establish and maintain a stable role in relations between the West and the Islamic world, and in particular between US policies and the challenges posed by the Islamic world.

\section{Three Logics of European Foreign Policy}

European foreign policy has developed during the past forty years (taking the Hague Summit of 1969 as a key initial step) in response to three logics. The first is the logic of the integration process, which creates pressures for institutional change and policy innovation as a means of stabilising and consolidating the internal forces released by 'ever-closer union'. The second is the logic of the external opportunity structure, which creates opportunities and challenges for an integrating Europe in the world arena, and which thereby can demand change and innovation at the level of international action. The third logic is that of European identity, which creates pressures for 'self-recognition' and the projection of a specifically European collective position on the world stage, often but not always in contradistinction to the positions of other leading actors. In reality, of course, these logics do not exist in separate compartments, and in many ways there is a 'fourth logic', a logic of linkages and reinforcements or contradictions between the three core logics. 
How do these logics show themselves in the development and the key characteristics of European foreign policy? The first logic, relating to the integration process, has several manifestations. One of these goes back to the very early characterisation of the integration process as one of 'spillover' (M. Smith 1998): to put it crudely, the development of internal integration creates a demand for integration of external actions, and thus leads to institutional change and policy innovation accompanied by 'externalisation' of integration needs. Alongside this process has gone another one: the process of institutional change itself, which has led to the embedding of European foreign policy into an increasingly dense set of institutional arrangements, and to the generation of accompanying networks and policy communities that demonstrate the effects of successive institutional bargains (M.E. Smith 2003). At times, because of the ways in which these two processes - of spillover and of institutionalisation - have interacted, it has become clear that the development of European foreign policy can be important to the further consolidation of internal integration, providing a kind of feedback or safetyvalve that can counteract some of the problems encountered with internal initiatives (Gnesotto 2005; M.E. Smith 2003, 2004). Recognition of the interactions between the emerging European foreign policy and the internal integration process is thus of considerable importance for the understanding of both.

But there is another aspect of the internal integration logic that is significant: the ways in which the construction of a European foreign policy has to accommodate the continued existence and in many areas the dominance of the EU's Member States. Despite the advances embodied in the Common Foreign and Security Policy (CFSP) and the European Security and Defence Policy (ESDP) since the beginning of the 1990s, there is still a very substantial inter-governmental component to European foreign policy, and it is difficult to see this as disappearing in the near future. What this means is that in addition to the linkage between the internal integration logic and the development of European foreign policy, we also need to recognise a kind of 'disintegration logic' or 'variable geometry' in areas where the needs of individual Member States take priority over those of European collective action. Adrian Hyde-Price has argued that this effectively reduces European 
foreign policy to dealing with 'second order' issues that Member States are willing (at least temporarily) to concede to the European level (Hyde-Price 2007 , 2008). The reasons for this may be positive - the desire to contribute to collective action on problems shared by all Member States - or more negative, reflecting the desire to shift the blame for areas of controversy or difficulty away from the national level. But there is little doubt that this interaction between Member State preferences and European collective action will persist in European foreign policy.

The second logic on which I focus here is the 'external' logic reflecting the international opportunity structure that confronts the EU and European foreign policy. There is little doubt that this structure has changed markedly since the first limited commitments to European Political Cooperation in the late1960s. During the Cold War period, moves towards European foreign policy were in many ways 'contained' by the predominant logic of relations between the then Superpowers and by the maintenance of the Western Alliance. As this structure loosened during the 1980s, there was more space for the development of European foreign policy cooperation, and this was reflected in the Single European Act of 1986 - the first document to embed the notion of foreign policy cooperation as a key element of the European integration process. But the SEA still reflected the severe constraints imposed by the primacy of NATO and the logic of Cold War politics.

The end of the Cold War in the late 1980s and early 1990s transformed many aspects of this situation. First, the predominance of the Superpower duopoly was challenged and then largely eliminated. Second, within Europe itself the demand for stabilisation based around the 'zone of peace' created by the European integration process was tangible and challenged the EC/EU in areas where they had a comparative advantage: the creation of a 'community of law' and the inculcation of legal, administrative and market structures that had deep effects on the countries to which they were applied. This is the basis of the argument that enlargement during the 1990s and early 2000s has been the most successful 'European foreign policy', giving the EU a major if not dominant role in the emerging European order (K. Smith 2003, 2005b; M. Smith 2007b). Accompanying this process has been that of globalisation, through which the connectedness of national societies has become ever 
deeper and the transmission of international 'goods' and 'bads' has become ever swifter. The status of the EU as a continental model of economic and social organisation might be seen as giving a strong basis here for the development of European foreign policy, but in many ways the strengths that give the EU a major role in the European order do not export easily; they are less immediately appropriate to a fluid and often chaotic world, and this means that the attempt to project 'Europe' into the global arena brings with it new risks and potential costs (see below).

The preceding raises a key question: what is demanded by the changed opportunity structure in the world arena, and can the EU supply it through European foreign policy? The most obvious manifestation of this question is in the relationship between 'soft' or 'civilian' power and 'hard' power - the former based on persuasion, negotiation and reward, the latter on coercion and threats of punishment (Nye 2004). The conventional wisdom, both among policy analysts and policy-makers in the EU, was for a long time that the European integration process led logically to the development and deployment of 'soft power', and in many cases there was an assumption that this was not only the practical but also the desirable position. Especially compared to the Superpowers (and then to the United States as the 'only Superpower') the EU held a position of comparative advantage, in which they could work in non-threatening ways to contribute to the world arena - to emphasise, in Arnold Wolfers' terms, 'milieu goals' rather than 'possession goals' (Wolfers 1962). The logic also led towards an emphasis on multilateral cooperation and institutions, in which the European could also be seen as holding a comparative advantage because of their long history of intensive cross-national collaboration.

But the logic of the post-Cold War, globalised world does not accommodate such a position so easily. The intensification of linkages between economics, diplomacy and security is well-established, and in fact preceded by some distance the end of the Cold War itself. At the same time, the speed of transmission of global 'goods' and 'bads' already mentioned creates a premium on rapid adaptation and innovation in foreign and security policy - a challenge that arguably the EU's institutional and political set-up does not suit it to meet. Here, of course, we see a clear linkage between the 
internal logic of the integration process and the external logic of international challenges and opportunities, since it is the strength and complexity of the internal process that might be seen as a disadvantage in responding creatively to external challenges or opportunities. The result has been a continuous search in the EU, since the end of the Cold War, for institutional fixes that can allow it to move collectively in response to global challenges and opportunities, but at the same time the persistence of contradictions that testify to the continuing power of the Member State perspective (Hill 2004).

It is clear from the argument so far that both the 'integration' logic and the 'external' logic of European foreign policy are the source of contention and potential contradiction. Alongside them, we have to consider a third logic: the 'identity' logic. Exploration of this logic has been at the centre of much analysis of European foreign policy since the end of the Cold War, and of the specific issues attaching to such areas as enlargement, development and human rights (Manners 2002, 2007; K. Smith 2003; Sedelmeier 2005, 2006). The search for a collective European identity, and the creation of collective European experience as a contribution towards that identity, has inevitably been fostered by the collapse of the Cold War structures and by the fracturing of seemingly solid identities that has gone along not only with the end of the Cold War but also with the march of globalisation. European foreign policy in this context has been driven not only by the needs of the integration process and by external challenges and opportunities, but also by a search for meaning and collective experience at the European level, and then by the projection of this meaning and experience into the global arena. What matters to this logic is the nature of social experience and social learning in the EU, among both policy-makers and other groups within European society, and the ways in which this changes understandings of the appropriate role(s) for the EU in international politics.

At one level, this is an analytical logic, applied by those investigating the development of European foreign policy and attempting to explain why it has fostered and projected a specific set of norms and values - for example multilateralism, deliberation, human rights, comprehensive security, cosmopolitanism. At another level, the realisation of the identity logic reflects the search by policy-makers themselves for a narrative that can articulate 
something specifically 'European' and which reflects the construction of 'policy-maker theories' about the world and Europe's role(s) within it. The impact of a search for appropriate European identities and roles through the medium of European foreign policy thus remains a key dimension of the overall development and consolidation of that policy. Not only this, but norms and values have become part of the stock in trade of EU policy-makers, and part of the ways in which they frame their approaches to specific regions or issues in the global arena (Bicchi 2007; Panebianco 2006; Smith and Vichitsorasatra 2007). Arguments have been made to the effect that the impact of these norms and values takes the EU beyond the status of 'normative power' and enables it to act as a 'civilising power' by creating or contributing to structures of global or regional governance or by pursuing conditionality in key areas of policy implementation (Linklater 2005; K. Smith 2003; Laatikainen and Smith 2006). Here, though, there is a need to be careful: first, the impact of the EU's 'civilising' actions may not be experienced or understood as civilising by their targets, and second, there is evidence of frequent and perhaps increasing inconsistency between the EU's words and its deeds in such areas as trade policy, to the extent that it casts doubt on the 'normative' character of the policies themselves (Jørgensen 2006). Finally, it is important here as elsewhere to note that the 'European' level of identification with norms, values and policies has to compete within Europe itself with long-established or resurgent national forces that will not soon disappear.

What does this examination of the three logics tell us about the changing nature of European foreign policy? First, it is clear that the three logics are not self-contained, insulated one from the others. They interact, and in the interaction can be found important pointers towards the past, current and future development of European foreign policy. Second, their interaction has become more intensive during the past fifteen years, when the end of the Cold War, the emergence of a new world (dis)order, institutional change and policy innovation in the EU and the increasing consciousness of European collective distinctiveness on the world stage have come together to create new momentum towards a European foreign policy. Third, that momentum has not been continuous or always cumulative; the process has been lumpy 
and spasmodic, since all three of the logics have not always pointed in the direction of increased European foreign policy development.

The interaction of the three logics is given added point by the impact of September $11^{\text {th }} 2001$ (Hill 2004, M. Smith 2006). Although it did not begin in 2001, during the period since ' 9.11 ' there has been a persistent push towards greater institutionalisation of security and defence policy in the EU, and the 'securitisation' of additional areas of European integration more generally, reflecting the operation of the 'integration logic'. This has been reinforced at important points by the 'external logic' of demands from the world arena, on the one hand from the United States through the 'war on terror', and on the other hand through the development of opportunities in Africa and elsewhere for the deployment of EU-badged forces. There has also been a continuing role for the 'identity logic', in respect of alignment with or separation from US policies, and in relation to the increased pressures for a 'hardening' of EU power through the development of military capacities, but this logic has not been without its areas of contention or conflict. The result is a set of trends and tensions that has arguably become more severe as the post-9.11 period has evolved, and which promises to become more severe still.

My argument is that this set of growing tensions, contradictions and concerns is focused and concentrated by the ways in which the EU has been confronted with the demands emanating from the 'triangle of forces' existing between the EU, the United States and the Islamic world. In the next section of the paper, I explore this 'triangle of forces' and attempt to clarify its implications for the current and future development of European foreign policy, with reference to the three logics and the range of forces identified in this section.

\section{Responding to the Islamic World and the United States: The EU and the 'Triangle of Forces'}

In this part of the article, I move from discussion of the development of European foreign policy to discussion of the ways in which it locates itself between the complex and challenging forces of the Islamic world and the United States. Before developing the argument it is important to establish an understanding of what some of the key terms used here are taken to mean. 
The first of these is 'the Islamic world'. This might be understood as 'the Muslim world' (implying the world of Muslim countries), or alternatively as 'the world of Islamist ideologies' (which may or may not be associated with particular Muslim countries), or alternatively as 'the world of Muslim people' (whether or not they are associated with a particular Muslim country or associate themselves with Islamist ideologies). For the European Union, in fact, all three of these manifestations coexist in the making of European foreign policy: they intersect with the logics of European foreign policy by forming part of the politics of integration within Europe (through the presence of Muslim populations within the EU), by forming part of the external structure of opportunities or constraints (especially through the EU's relations with Muslin countries, but also through the activities of transnational Muslim groupings), and by constituting a challenge - or an alternative - to notions of a European identity in the changing world arena (see for example Asad 2002, Hunter 2002: Part III, Shadid and van Koningsveld 2002, Savage 2004, Zemni 2002).

A second key term that demands definition is 'United States'. For the entire life of the European integration project, the USA has been Europe's most significant 'other'. Its impact on European foreign policy, though, has been ambiguous throughout. American attitudes towards European integration have been ambivalent: at the broadest level, support for the project as a stabilising and energising force, but at the level of policy detail a continuing preoccupation with the challenge posed by 'Europe' as an economic and (increasingly) a diplomatic power. At the same time, American actions in the world arena have formed a fluctuating backdrop for the development of European foreign policy, and have been seen since at least the late 1960s as a source of risk and possible danger (McGuire and Smith 2008: chapters 1 and 9; Peterson and Pollack 2003). Not surprisingly, therefore, the pursuit of European identity in the world arena has developed partly as a means of focusing difference between the EC/EU and the United States, and has been sharpened and often crystallised by US actions in such theatres as Southeast Asia, Afghanistan and the Persian Gulf. Just as with the Islamic world, therefore, the United States intersects with and complicates the three logics of European foreign policy. 
The argument here is that the intersection of the Islamic world (defined broadly as above) and the United States (in its fluctuating manifestations) with European foreign policy creates a 'triangle of forces' to which the Europeans have had to respond. It is tempting to consider this 'triangle of forces' between the EU, the US and the Islamic world in rather traditional terms (for example, Savage 2004). On the one side, there is the power and potential hegemony of the world's only Superpower, which at least during the past few years has been expressed in notably unilateral and confrontational terms. On the other side, there is the challenge of dealing with a wide range of countries from Morocco to Indonesia that have major Muslim populations and that are in many cases strategically important both to the EU and to the United States. Such an analysis has the strength that it promises to identify the key strategic challenges and opportunities for the $\mathrm{EU}$, and to show how the $\mathrm{EU}$, with its partial but growing European foreign policy, might respond to them. And of course, such an analysis is often conducted by those who emphasise the role of European foreign policy as a form of balancing (either 'soft' or now 'harder') between contending external forces, or those who see the key aims of the EU as ensuring a stable and orderly international arena in which it can pursue its objectives as a 'trading state' (M. Smith 2004; Pape 2005). In this way, the EU's situation between the United States and the Islamic world privileges what we earlier described as the 'external logic' of European foreign policy: the challenges and opportunities are out there and the task is to steer between them using the instruments of European foreign policy.

The reality, however, is not so simple, and it challenges the presumption that there might be a unified or uniform 'European' approach to foreign policy in this area. What appears to be a triangle of (separate) forces is in reality a deeply interpenetrated set of relationships, in which the EU finds itself a central focus and which (as outlined above) intersects with the three central logics of European foreign policy. The United States is not just 'out there' for the EU: it is inside the EU culturally, economically, politically and in terms of the strategic practices and priorities to which most European defence establishments still subscribe. In a similar way, the Islamic world is not just 'out there': it exists within the EU in terms of domestic Islamic populations, and in terms of cultures that have been shaped by the results of many 
centuries of interaction. As noted above, neither the American nor the Islamic presence is uniform and unvarying, but neither can be ignored as a factor in the internal European integration process. In this way, the 'triangle of forces' intersects with the 'integration logic' in the EU and in European foreign policy to shape the ways in which European foreign policy-makers approach their external tasks.

The 'triangle of forces' also intersects with the 'identity logic' of European foreign policy, since it presents the Europeans with competing 'others' and with the need to define 'Europeanness' in some ways as distinct from both the United States and the Islamic world. This is not an easy task, given the admitted difficulties of defining a European identity for a Union of 27 Member States, and it is of course complicated further by the unevenness of experience and contact between the Member States and both of these outside forces. It has often been noted that a number of EU Member States have 'special relationships' with the USA, but it is equally significant that many of them also have 'special relationships' with the Islamic world, whether this is through the presence of Muslims in domestic populations, through the historical impact of colonialism and its legacy, or through the impact of Islamic ideas within European cultures (Kumar 2002). As noted earlier in the paper, the internal balances of preferences and normative positions among EU Member States are a constantly shifting element in the definition of European foreign policy and of European roles in the global arena, and the conflicting demands posed by a domineering and challenging USA and a highly varied but equally challenging Islamic world make the development of a 'European' consensus all the more difficult.

So, to put it simply, the EU is stuck in a position where the three logics driving the development of European foreign policy are intersected by the often contradictory logics of relations with the USA and the Islamic world. At the same time, I would also argue that the 'triangle of forces' is a key complicating element (but also a key catalyst) in the more specific trends and tensions identified in the second part of this paper. The deteriorating but intense relations between the USA and some Islamic countries, and its overspill into broader 'Western' conceptions of Islam, have set the EU and its developing foreign policy a set of almost impossible tasks, given what we 
know about the forces shaping that foreign policy in more general terms. In the first place, the 'triangle of forces' has played a key role in intensifying the 'securitisation' of European foreign policy, and in driving the shift towards 'security policy' rather than diplomacy or defence policy. This in turn has pushed the EU further onto very difficult terrain, where the risks not only in terms of foreign policy but also in terms of 'societal security' are difficult to estimate or to confront.

Paradoxically, it could be argued that the EU's move via the ESDP into a 'harder' defence policy posture has not really reflected the 'triangle of forces' up to now; rather, the focus has been on tasks such as conflict prevention and peacekeeping in areas where relations between the US and the Islamic world are less prominent, or on civilian reconstruction where they are an issue (Howorth 2007: chapter 7). The EU has not taken on a military or security role directly in Iraq or Afghanistan, for example. The exceptions that may or may not prove the rule relate to the Palestinian territories, where the EU has provided border monitoring and policing support through civilian missions since 2005, and the Lebanon, where the EU (or rather a group of EU Member States) has emerged as a sub-contractor (informally if not formally) for the UN in an area where the US feels it cannot be directly engaged on the ground (Keukeleire and MacNaughtan 2008: chapter 7). The EU's role in both of these cases is a matter of very delicate negotiation and balancing both within and outside the European policy process, and it remains to be seen whether a marked deterioration in conditions within Palestine or within Lebanon itself would meet with a robust EU response.

The expansion of the EU's 'defence perimeter' through enlargement and the European Neighbourhood Policy (ENP) clearly brings it into much closer contact with the 'triangle of forces' in geo-political terms. This has arguably been the case for some time given the intersection of US policies with Islamic populations in the former Yugoslavia, but it has become more marked in recent years with the development of the ENP and the prospect of enlargement to include Turkey. A key point to be made here is precisely that for the EU, the 'triangle of forces' has a much more tangible geopolitical meaning than it does for the United States or for Islamic countries: the EU is literally at the intersection, the ENP extends to include many Islamic countries 
from the Maghreb to central Asia, and if Turkey joins there will be an EU border with Syria, Iraq and Iran. From the point of view of the internal EU integration process, such developments intensify existing differences of priority and perspective that have direct implications for the future development of the Union. In terms of European foreign policy, they mean a highly complex geopolitical as well as geo-cultural balancing act, which is complicated further by the internal differences we have noted.

It is to be expected, therefore, that the tensions and contradictions outlined in the previous section will be exacerbated to the extent that they are intersected by the 'triangle of forces'. The coexisting trends towards 'widening', 'deepening' and 'hardening' in European foreign and security policy (through enlargement, institutional change and the development of the ESDP) have in many ways been at the heart of the discussion in this section so far. They have simultaneously put the EU in a position where it cannot ignore the challenges posed by the 'triangle of forces' and rendered more complex the balancing act that has to be performed between its elements. As a result, the often conflicting pressures towards 'renationalisation' through an increased role for Member States, 'regrouping' through the development of 'coalitions of the willing' and 'Europeanisation' through the intensification of ESDP and CFSP alike can be expected to grow (Hill 2004, Smith 2006). The evidence from Iraq 2003, to a degree from Afghanistan since 2001, and from Lebanon 2006 is that these forces form a constant challenge to the framing and implementation of EU actions, and that the 'triangle of forces' poses questions that are very difficult to answer in the current state of European foreign policy. In the same way, the related tensions between multilateralism and minilateralism in European foreign policy can be and have been exacerbated by the 'triangle of forces' as expressed in recent conflicts: the Iraq crisis of 2003 saw constant manoeuvring on this front, the unevenness of European burden-sharing in Iraq may not specifically be an EU problem but it feeds back into perceptions of commitment to EU collective action elsewhere, and the Lebanon crisis saw similar tensions. EU policy towards Iran, focused on pursuit of a diplomatic solution and led by the 'EU-3', has perhaps been more of a European foreign policy success story, but it is difficult to estimate what the effects might be of a severe escalation of tensions (Posch 2006). 
Does this mean that the veneer of collective commitment to European foreign policy is especially likely to shatter if subjected to challenge from the 'triangle of forces' between the EU, the US and Islam? The implication of the preceding argument is that both the United States and Islam have distinctive capacities to create tensions within European foreign policy, and that their mutual relations can put the EU and its Member States in very difficult positions. Solidarity in these conditions is not easy to achieve, and defection from apparently agreed positions is all too easy to contemplate. This need not mean that European foreign policy as a whole is undermined, as evidenced by the operations carried out in sub-Saharan Africa and elsewhere during the past decade. The problem is that the extension and intensification of the tensions between the US and the Islamic world might reduce the amount of 'space' in the world arena for the EU, and might politicise in a new way some of those areas where the EU has been able to undertake significant foreign policy initiatives in the past, thus exacerbating the differences of perspective within the EU itself and throwing into question the legitimacy of European foreign policy.

In this context, the whole question of a European 'civilising project' is of central importance (Linklater 2005). If that is construed as a mediating project in a broader 'clash of civilisations', then the outlook might be bleak given the lack of room for manoeuvre available to the Union between the contending forces of the US and the Islamic world. On the other hand, if the 'civilising project' is seen as a way of understanding and responding to difference within the West and the Islamic world, then there is far more of a prospect that European foreign policy might have a truly civilising effect, by exploiting the space for diplomacy and for forms of balancing within and between the 'triangle of forces'. A note of caution must of course be entered here: the divisions referred to run through the EU as well as between the US and the Islamic world, so any effective use of European foreign policy mechanisms would need to confront that set of cleavages before setting about an external 'civilising mission'. 


\section{Conclusion: European Foreign Policy Between the United States and the}

\section{Islamic World: Catalysed or Constrained?}

Two possible trajectories for European foreign policy can be derived from the argument in this article. The first sees European foreign policy as potentially or actually catalysed by the coming together of developments in the policy process and in European capabilities, and capable of taking the appropriate initiatives to extend the scope and impact of the European Union within the 'triangle of forces'. In this trajectory, the EU becomes more capable of resolving internal differences, of discerning external opportunities and of developing a shared view of the kind of international order it wants to pursue. This in turn would enable the EU to move beyond its role as an 'intersection' in the 'triangle of forces' and to advance credible alternative positions, if necessary backed up by 'hard power'. As noted above, this is a relatively high-risk trajectory, since it entails the forsaking of a 'civilian power' role and the development of a far more muscular approach both to the United States and to Islamic countries or movements.

The second possible trajectory for European foreign policy can be described as 'constrained'. In this trajectory, the diversity of internal preferences prevents the EU from adopting a clear position based on integration logic; as a result, external opportunities or challenges are not exploited or confronted in a direct way; and there is a conscious attempt either to play down the possibility of a common European understanding of the EU's role(s) or to settle for a common conception of a minimalist role designed to preserve the EU's trading priorities and to avoid confrontations either with the United States or with the Islamic world. This might be described as a low-risk trajectory, since its key element is the avoidance of confrontation and the preservation of core EU values at the expense of international activism.

The reality is that the EU is not really in a position to choose one or the other of these trajectories. As argued in this article, it has already been pushed onto terrain where the risks are higher, the potential costs higher and the stakes both for the EU and its Member States higher. The interaction of the three foreign policy logics outlined in this paper has created a kind of ratchet effect, where there is no going back to the safer terrain of 'soft' or 'civilian power'. When to the interaction of the three logics is added the 
operation of the 'triangle of forces', the EU and its Member States find themselves with little room for manoeuvre, because of the ways in which these linked forces converge on the principles and practice of European foreign policy. There may well be arguments within the EU, both at the level of the policy community and at a broader popular level in the context of treaty ratification, about the choices that the EU ought to make. But in many ways these are arguments at the margin, about how to respond to the situation in which the EU now finds itself. As argued in this paper, this situation can best be characterised as 'between "soft power" and a hard place'. 


\section{REFERENCES}

Aggestam, L. (2004), A European Foreign Policy? Role Conceptions and the Politics of Identity in Britain, France and Germany. Stockholm Studies In Politics, 106, Stockholm: Stockholm University Department of Political Science.

Aggestam, L. (ed) (2008), 'Ethical Power Europe?', International Affairs Special Issue 84(1), January.

Allen, D. and Wallace, W. (1967), 'Political Cooperation: Procedure as a Substitute for Policy' in Wallace, H., Wallace, W. and Webb, C. (eds), Policy-Making in the European Communities, Chichester: Wiley.

Allen, D. and Pijpers, A. (eds) (1982), European Foreign Policy and the ArabIsraeli Dispute, London: Butterworth.

Allen, D. and Smith, M. (1989), 'Western Europe in the Atlantic System of the 1980s: Towards a New Identity?', in S. Gill (ed) Atlantic Relations: Beyond the Reagan Era, Brighton: Harvester/Wheatsheaf.

Asad, T. (2002), 'Muslims and European Identity: Can Europe Represent Islam?' in Pagden. A. (ed), The Idea of Europe: From Antiquity to the European Union, Cambridge: Cambridge University Press.

Barysch, K., Everts, S. and Grabbe, H. (2005), Why Europe Should Embrace Turkey, London: Centre for European Reform

Bicchi, F. (2007), "'Our Size Fits All": Normative Power Europe and the Mediterranean' in Sjursen, H. (ed), Civilian or Military Power? European Foreign Policy in Perspective, London: Routledge.

Elgström, O. and Smith, M. (eds) (2006), The European Union's Roles in International Politics: Concepts and Analysis, London: Routledge.

Forster, A. and Wallace, W. (1996), 'Common Foreign and Security Policy: A New Policy or Just a New Name?' in Wallace, H. and Wallace, W. (eds), Policy-Making in the European Union, $3^{\text {rd }}$ edition, Oxford: Oxford University Press.

Forster, A. and Wallace, W. (2000), 'Common Foreign and Security Policy: From Shadow to Substance?' in Wallace, H. and Wallace, W. (eds), Policy-Making in the European Union, $4^{\text {th }}$ edition, Oxford: Oxford University Press.

Gnesotto, N. (2005), 'La PESC en antidote', European Union Institute for 
Security Studies Bulletin 16, December.

Gnesotto, N. and Grevi, G. (eds) (2006), The New Global Puzzle: What World for the EU in 2020? Paris: European Union Institute for Security Studies.

Grevi, G. (2008), 'The EU and Global Governance: Rules, Power and Priorities', Report on a Seminar held in Cooperation with the Istituto Affari Internazionali, Paris: European Union Institute for Security Studies, $25^{\text {th }}$ June.

Hill, C. (2004), 'Renationalising or Regrouping? European Foreign Policy Since $11^{\text {th }}$ September 2001', Journal of Common Market Studies 42(1): 143-63.

Hill, C. and Smith, M. (eds) (2005), International Relations and the European Union, Oxford: Oxford University Press.

Howorth, J. (2005), 'From Security to Defence: The Evolution of the CFSP' in Hill, C. and Smith, M. (eds), International Relations and the European Union, Oxford: Oxford University Press.

Howorth, J. (2007), Security and Defence Policy in the European Union, Basingstoke: Palgrave/Macmillan.

Hunter, S. (ed) (2002), Islam, Europe's Second Religion: The New Social, Cultural and Political Landscape, Westport, CT: Greenwood Press for the Center for Strategic and International Studies.

Hyde-Price, A. (2007), '”'Normative" Power Europe: A Realist Critique' in Sjursen, H. (ed), Civilian or Military Power: European Foreign Policy in Perspective, London: Routledge.

Hyde-Price, A. (2008), 'A "Tragic Actor"? A Realist Perspective on Ethical Power Europe' in Aggestam, L. (ed), 'Ethical Power Europe?', International Affairs Special Issue 84(1), January.

Jørgensen, K.E. (2006), 'A Multilateralist Role for the EU?' in Elgström, O. and Smith, M. (eds), The European Union's Roles in International Politics: Concepts and Analysis, London: Routledge.

Kumar, K. (2002), 'The Nation-State, the European Union and Transnational Identities', in Alsayyad, A. and Castells, M. (eds), Muslim Europe or Euro-Islam: Politics, Culture and Citizenship in the Age of Globalization, Lanham, MD: Lexington Books. 
Laatikainen, K. and Smith, K. (eds), The European Union at the United Nations: Intersecting Multilateralisms, Basingstoke: Palgrave/Macmillan.

Linklater, A. (2005), 'A European Civilising Process?' in Hill, C. and Smith, M. (eds), International Relations and the European Union, Oxford: Oxford University Press.

Manners, I. (2002), 'Normative Power Europe: A Contradiction in Terms?', Journal of Common Market Studies 40(2): 234-58.

McGuire, S. and Smith, M. (2008), The European Union and the United States: Competition and Convergence in the World Arena, Basingstoke: Palgrave/Macmillan.

Miliband, D. (2007), 'Europe 2030: Model Power Not Superpower', Speech delivered at the College of Europe, Bruges, $15^{\text {th }}$ November. Found at http://www.fco.gov.uk/servlet/Front/Print?pagename=OpenMarket/Xcel erate/ShowPage $\& c=$ Page $\&$ cid $=1007029391647 \& a=$ KArticle $\&$ aid $=1194$ $715986447\left(16^{\text {th }}\right.$ December 2007).

Nuttall, S. (1992), European Political Cooperation, Oxford: Clarendon Press.

Nuttall, S. (2000), European Foreign Policy, Oxford: Oxford University Press. Nye, J.S. (2004), Soft Power: The Means to Success in World Politics, New York: Public Affairs.

O'Donnell, C. (2008), The EU, Israel and Hamas, London: Centre for European Reform.

Ortega, M. (ed), The European Union and the Crisis in the Middle East, Chaillot Paper 62 (Paris: EU Institute for Security Studies)

Panebianco, S. (2006), 'The Constraints on EU Action as a "Norm Exporter" in the Mediterranean' in Elgström, O. and Smith, M. (eds), The European Union's Roles in International Politics: Concepts and Analysis, London: Routledge.

Pape, R. (2005), 'Soft Balancing Against the United States', International Security 30(1): 7-45.

Peterson, J. (1996), Europe and America: The Prospects for Partnership. $2^{\text {nd }}$ edition, London: Routledge.

Peterson, J. and Sjursen, H. (eds) (1998), A Common Foreign Policy for Europe? Competing Perspectives on the CFSP, London: Routledge. 
Peterson, J, and Pollack, M. (eds) (2003), Europe, America, Bush:

Transatlantic Relations in the Twenty-First Century, London:

Routledge.

Posch, W. (ed) (2006), Iranian Challenges, Chaillot Paper 89, Paris:

European Union Institute for Security Studies.

Savage, T. (2004), 'Europe and Islam: Crescent Waxing, Culture Clashing', Washington Quarterly 27(3): 25-50.

Sedelmeier, U. (2005), Constructing the Path to Eastern Enlargement: The Uneven Policy Impact of EU Identity. Manchester: Manchester University Press.

Sedelmeier, U. (2006), 'The EU's Role as a Promoter of Human Rights and Democracy: Enlargement Policy Practice and Role Formation' in Elgström, O. and Smith, M. (eds), The European Union's Roles in International Politics: Concepts and Analysis, London: Routledge.

Shadid, W. and van Koningsveld, P. (2002), 'The Negative Image of Islam and Muslims in the West: Causes and Solutions', in Shadid, M. and van Koningsveld, P. (eds), Religious Freedom and the Neutrality of the States: The Position of Islam in the European Union, Leuven: Peeters.

Sjursen, H. (2003), 'Understanding the Common Foreign and Security Policy: Analytical Building-Blocks', in Knodt, M. and Princen, S. (eds), Understanding the European Union's External Relations, London: Routledge.

Sjursen, H. (ed) (2007), Civilian or Military Power? European Foreign Policy in Perspective, London: Routledge.

Smith, K. (2003), European Union Foreign Policy in a Changing World. Cambridge: Polity.

Smith, K. (2005a), 'Beyond the Civilian Power EU Debate', Politique Européenne 17: 63-83.

Smith, K. (2005b), 'Enlargement and European Order' in Hill, C. and Smith, M. (eds), International Relations and the European Union, Oxford: Oxford University Press.

Smith, M. (1998), 'Does the Flag Follow Trade? "Politicisation" and the Emergence of a European Foreign Policy', in Peterson, J. and Sjursen, H. (eds), A Common Foreign Policy for Europe? Competing Visions 
of the CFSP, London: Routledge.

Smith, M. (2003), 'The Framing of European Foreign and Security Policy:

Towards a Post-Modern Policy Framework?', Journal of European Public Policy 10(4): 556-75.

Smith, M. (2004), 'Between Two Worlds? The European Union, the United States and World Order', International Politics 41(1): 95-117.

Smith, M. (2005), 'Taming the Elephant? The European Union and the Management of American Power', Perspectives on European Politics and Society 6(1): 129-54.

Smith, M. (2006), 'The Shock of the Real? Trends in European Foreign and Security Policy Since September 2001', Studia Diplomatica LIX(1): 27-44.

Smith, M. (2007a), 'Comment: Crossroads or cul de sac? Reassessing European Foreign Policy', in Sjursen, H. (ed), Civilian or Military Power? European Foreign Policy in Perspective. London: Routledge.

Smith, M. (2007b), 'The European Union and International Order: European And Global Dimensions', European Foreign Affairs Review 12(4): 43756.

Smith, M. and Vichitsorasatra, N. (2007), 'The European Union as a Foreign Policy Actor in Asia: Theorising and Defining EU-Asia Relations' in Anderson, P. and Wiessala, G. (eds), The European Union and Asia: Reflections and Reorientations, Amsterdam and New York: Rodopi.

Smith, M.E. (2003), Europe's Foreign and Security Policy: The Institutionalisation of Cooperation, Cambridge: Cambridge University Press.

Smith, M.E. (2004), 'Toward a Theory of EU Foreign Policy-Making: MultiLevel Governance, Domestic Politics, and National Adaptation to Europe's Common Foreign and Security Policy', Journal of European Public Policy 11(4): 740-58.

Wallace, W. (2005), 'Foreign and Security Policy' in Wallace, H., Wallace, W. and Pollack, M. (eds), Policy-Making in the European Union. $5^{\text {th }}$ edition, Oxford: Oxford University Press.

White, B. (2001), Understanding European Foreign Policy, Basingstoke: Palgrave/Macmillan. 
Wolfers, A. (1962), 'The Goals of Foreign Policy', in Discord and Collaboration: Essays on World Politics, Baltimore, MD: Johns Hopkins University Press.

Youngs, R. (2006), Europe and the Middle East: In the Shadow of September 11, Boulder, CO and London: Lynne Rienner.

Zemni, S. (2002), 'Islam, European Identity and the Limits of Multiculturalism', in Shadid, W. and van Koningsveld, P. (eds), Religious Freedom and the Neutrality of the State: The Position of Islam in the European Union, Leuven: Peeters 